\title{
Study on Zooplankton Diversity and Physico Chemical Parameter of Pampoo Pond of Madhupur, Jharkhand, India
}

\author{
Seema Singh ${ }^{1}$, Erum Usmani ${ }^{1}$, Riya Dutta ${ }^{1}$, Veena Kumari ${ }^{1}$, Salma Praveen ${ }^{1}$, Swati Kumari ${ }^{1}$, \\ Basant Kumar Gupta ${ }^{1}$, Mohommad Arif ${ }^{2}$ \\ ${ }^{1}$ Deoghar College, Deoghar under Sido Kanhu Murmu University, Jharkhand-814112, \\ ${ }^{2}$ Defence Institute of Bio-Energy Research (DIBER),HQ, Haldwani,Uttarakhand- 263139, India.
}

*Correspondence E-mail : seemasinghania96@gmail.com

\begin{abstract}
Zooplankton are diverse in nature and they are found in almost all water bodies. The present study deals with the study of monthly changes of Zooplankton diversity and physico chemical parameters of Pampoo Pond of Madhupur, Jharkhand, India. Present study was carried out for a period of one-year from July 2019 to June 2020. Present study revealed 15 genera of Zooplankton from the fresh water pond belonging to the four groups namely Cladocera, Rotifera, Copepoda and Ostracoda. Among all four group maximum abundance of Cladocerans (34\%) were observed. Five species of cladocerans, five species of copepods, three species of rotifers and two species of ostracods were observed. The population density order observed as cladocerans $>$ copepods $>$ rotifers $>$ ostracods. Physico chemical parameters were analyzed as per methods described in APHA (1998) and was found under standard range.
\end{abstract}

Keywords: Zooplankton diversity, Physico chemical parameters, Pampoo Pond, water quality.

\section{Introduction}

Zooplankton are cosmopolitan in environment and one of the utmost important ecological parameter in water quality assessment because they help in clearance of sewage and act as natural cleansers of water. Zooplankton are a varied group of heterotrophic organisms that consume phytoplankton, regenerate nutrients via their metabolism and transfer energy to higher trophic levels (Steinberg and Robert, 2009). Zooplankton mediate the transfer of energy from lower to higher tropic level thus zooplankton represent an important link in aquatic food chain and contribute significantly to secondary production in fresh water ecosystem (Sharma, 1998). It plays an important role in recycling nutrients as well as cycling energy within their respective environment. These are the main sources of natural food for fish which is directly related to their survival and growth and are base of food chains and food webs in all aquatic ecosystem (Miah et.al. 2013). Zooplankton act as good indicator of variations in water quality because it is strongly affected by environmental conditions. That's why physico-chemical standards plays significant role in assessing the water quality of water body. Zooplankton communities respond to a wide variety of disturbances including nutrient loading, acidification and sediment input etc. The distribution and diversity of zooplanktons in aquatic ecosystems depend mainly on the 
seasonal variations and physicochemical parameters of water (Saba and Sadhu, 2015). It is a well-suited tool for understanding water pollution status (Contreras et al., 2009).

Aquatic diversity of lentic water bodies consists many organism but out of all zooplankton play an important role. Zooplankton is microscopic and free floating organisms which move at the compassion of the water movements and wind. They occupy transitional position in the food web. In fresh water pond generally zooplanktonic fauna consists of Protozoa, Rotifer, Cladocera, Copepoda and Ostracoda etc (Rajagopal et al., 2010). The diversity and abundance of zooplankton fluctuates with seasonal variations (Singh et al., 2021).

Methodical studies on the Indian zooplankton began more than a century ago (Edmondson, 1959; Battish, 1992). Extensive regional surveys on faunal variability and diversity of zooplankton in freshwater environment are still deficient. Some workers has been done study on zooplankton diversity from different parts of India (Sharma, 1998; Khan, 2003; Kar, 2007; Sharma and Sharma, 2008). Some reports from Kashmir (Khan 1987), Bihar (Rai and Datta, 1988), West Bengal (Khan, 2002 and 2003; Ganesan and Khan, 2008), Assam (Sharma and Sharma, 2008; Kar and Barbhuiya,2004), Manipur (Sharma, 2009), Assam(Kar and Kar, 2016) and Jamtara, Jharkhand (Singh et al., 2021)are also available.

Present work was done to assess the effect of seasonal variations (monthly) on diversity of zooplankton and physico chemical parameters of Pampoo Pondof Madhupur, Jharkhand. Present study was carried out keeping in view of above information and scarcity of literature from Jharkhand. Though few works on Zooplankton diversity was reported from Chaibasa, West Singhbhum (Sinha and Singh, 2016), Bokaro (Saba and Sadhu, 2016) and Jamtara (Singh et al., 2021) of Jharkhand but much more study is required from freshwater bodies of different parts of Jharkhand to establish a well-documented knowledge in area of zooplankton diversity and physico chemical parameters of pond. Thus the present study was an attempt for reporting effect of seasonal variations in Zooplankton diversity along with physico chemical parametrs of Pampoo Pond from Madhupur, Jharkhand.

\section{Materials and Method}

Pampoo Pondis located at Madhupur a subdivision of district Deoghar, Jharkhand. It lies between $24^{\circ} 26 \mathrm{~N}$ and $86^{\circ} 65^{\prime \prime} \mathrm{E}$. The artificial pond selected for the present study is small, open and shallow fresh water pond. The entire area is overwhelmingly rural with only small sacks of urbanization. The district is located at the low hills of plateau except the eastern portion where the Rajmahal hills intrude into this area and the Ramgarh hills are there. The south western portion is just a rolling upland.

Zooplankton sampling was conducted for a period of one year from July 2019 to June 2020. Zooplankton were sampled weekly from the site following the standard methods of Battish (1992).

Then the sample were filtered and placed in Tarson $(100 \mathrm{ml})$ container and fixed immediately with $4 \%$ formalin solution and stored in cool and dark place. For diversity study of Zooplankton sample were taken in a Sedgwick-Rafter counting chamber and observed under a light microscope under prerequisite magnification ( $10 \mathrm{X}$ initially than followed by $40 \mathrm{X}$ ) and the specimens were identified following standard literature of Battish (1992); Edmondson (1959); Michael and Sharma (1998); Sharma (1998); Sharma and Sharma (2008).

Physico-chemical characteristics of water like temperature, $\mathrm{pH}$, Total Hardness, Alkalinity, Dissolved Oxygen, Phosphate (PO4) and Nitrate (NO3)were studied at monthly intervals for a period of one year from July 2019 to June 2020 of Pampoo Pond by choosing fixed spot by composite sampling method using labelled plastic container of fiver litre capacity.

Water parameters were analysed as per methods described in APHA (1998). Temperature was noted down on the spot with the help of thermometer and further physicochemical parameters were analysed in laboratory. 


\section{Results}

Present study revealed 15 genera of Zooplankton from the fresh water pond belonging to the four groups namely Cladocera, Rotifera, Copepoda and Ostracoda. Among all four group maximum abundance of Cladocerans (34\%) were observed (Table 2). Five species of cladocerans, five species of copepods, three species of rotifers and two species of ostracods were observed.
The present investigation clearly showed that the maximum density and diversity observed between the months March to May and minimum in August, December and January.

The bar diagrams and table 1 presented below explained the variation pattern of different zooplanktons in all different months of the year.

Table 1 Abundance of Zooplankton species of Pampoo Pond of Madhupur from July 2019 to June 2020

\begin{tabular}{|c|c|c|c|c|c|c|c|c|c|c|c|c|}
\hline $\begin{array}{l}\text { ZOOPLA } \\
\text { NKTON }\end{array}$ & $\begin{array}{l}\text { JUL } \\
2019\end{array}$ & $\begin{array}{l}\text { AUG } \\
2019\end{array}$ & $\begin{array}{l}\text { SEP } \\
2019\end{array}$ & $\begin{array}{l}\text { OCT } \\
2019 \\
\end{array}$ & $\begin{array}{l}\text { NOV } \\
2019\end{array}$ & $\begin{array}{l}\text { DEC } \\
2019\end{array}$ & $\begin{array}{l}\text { JAN } \\
2020\end{array}$ & $\begin{array}{l}\text { FEB } \\
2020\end{array}$ & $\begin{array}{l}\text { MAR } \\
2020\end{array}$ & $\begin{array}{l}\text { APR } \\
2020\end{array}$ & $\begin{array}{l}\text { MAY } \\
2020\end{array}$ & $\begin{array}{l}\text { JUN } \\
2020 \\
\end{array}$ \\
\hline \multicolumn{13}{|c|}{ CLADOCERA } \\
\hline $\begin{array}{l}\text { Daphnia } \\
\text { sp. }\end{array}$ & 3 & 3 & 3 & 4 & 6 & 1 & 1 & 2 & 8 & 8 & 8 & 7 \\
\hline $\begin{array}{l}\text { Ceriodaph } \\
\text { nia sp }\end{array}$ & 2 & 2 & 4 & 5 & 4 & 6 & 8 & 7 & 4 & 3 & 5 & - \\
\hline $\begin{array}{l}\text { Alonella } \\
\text { sp. }\end{array}$ & 2 & 1 & 3 & - & - & - & - & - & 4 & 3 & 3 & 2 \\
\hline $\begin{array}{l}\text { Diaphanos } \\
\text { oma sp. }\end{array}$ & - & - & 2 & 1 & 1 & - & - & 3 & 2 & 1 & 2 & - \\
\hline Moina sp. & - & - & - & 1 & 1 & 1 & 1 & 1 & 2 & 4 & 6 & - \\
\hline \multicolumn{13}{|c|}{ COPEPODA } \\
\hline $\begin{array}{l}\text { Cyclops } \\
\text { sp. }\end{array}$ & 1 & 1 & 3 & 2 & 2 & 2 & 1 & 3 & 5 & 6 & 9 & 1 \\
\hline $\begin{array}{l}\text { Tropocycl } \\
\text { ops sp. }\end{array}$ & 1 & 2 & 1 & 1 & - & - & - & & 4 & 3 & 3 & - \\
\hline $\begin{array}{l}\text { Nauplius } \\
\text { sp. }\end{array}$ & 2 & 1 & 2 & 3 & 1 & 1 & 1 & 6 & 6 & 7 & 7 & 4 \\
\hline $\begin{array}{l}\text { Diaptomus } \\
\text { sp. }\end{array}$ & 1 & 1 & 1 & 1 & 1 & 2 & 2 & 1 & 4 & 3 & 1 & - \\
\hline $\begin{array}{l}\text { Heliodiapt } \\
\text { omus sp. }\end{array}$ & - & - & - & - & 1 & 1 & 2 & 1 & 6 & 6 & 7 & 4 \\
\hline \multicolumn{13}{|l|}{ ROTIFERA } \\
\hline $\begin{array}{l}\text { Brachionu } \\
\text { s sp. }\end{array}$ & 4 & 4 & 5 & 5 & 5 & 2 & 2 & 4 & 7 & 7 & 8 & 7 \\
\hline $\begin{array}{l}\text { Conochilu } \\
\text { s sp. }\end{array}$ & - & - & - & - & - & - & - & 3 & 5 & 5 & 5 & 2 \\
\hline Filinia $s p$. & 2 & 1 & 2 & 3 & 2 & 3 & 1 & 4 & 4 & 4 & 3 & 2 \\
\hline \multicolumn{13}{|c|}{ OSTRACODA } \\
\hline Cypris sp & 1 & 1 & 1 & 3 & 1 & 1 & 1 & 1 & 5 & 5 & 6 & 5 \\
\hline $\begin{array}{l}\text { Stenocypri } \\
\text { s sp. }\end{array}$ & - & - & 1 & 1 & - & - & - & - & 2 & 2 & 3 & 4 \\
\hline
\end{tabular}

\section{Cladocera}

Five species of cladocerans namely Daphnia sp, Ceriodaphnia sp, Alonella Sp, Diaphanosoma $s p$, and Moina sp were observed. Among all five species of cladocerans Daphnia $s p$ and Ceriodaphnia $s p$ were observed throughout the year but maximum species observed in month of May. The population of Daphnia $s p$ was found to be high from February to June in summer but decreased during rainy days and again increasing in winter but not like summers. The population density of Ceriodaphnia $s p$ was observed high in winters but low in summer and very less in rainy days. The abundance of Alonella $s p$. were decreased during rainy days and not observed in winter while Moina $s p$ 
Int J Adv Life Sci Res. Volume 4(4)34-44

population decreased in winter and not observed in rainy days.

The occurrence of Diaphanosoma sp found all the year except December and January during winter. During the present study, cladocera group was reported to be dominant among all other Zooplankton groups during study period (Figure 1).

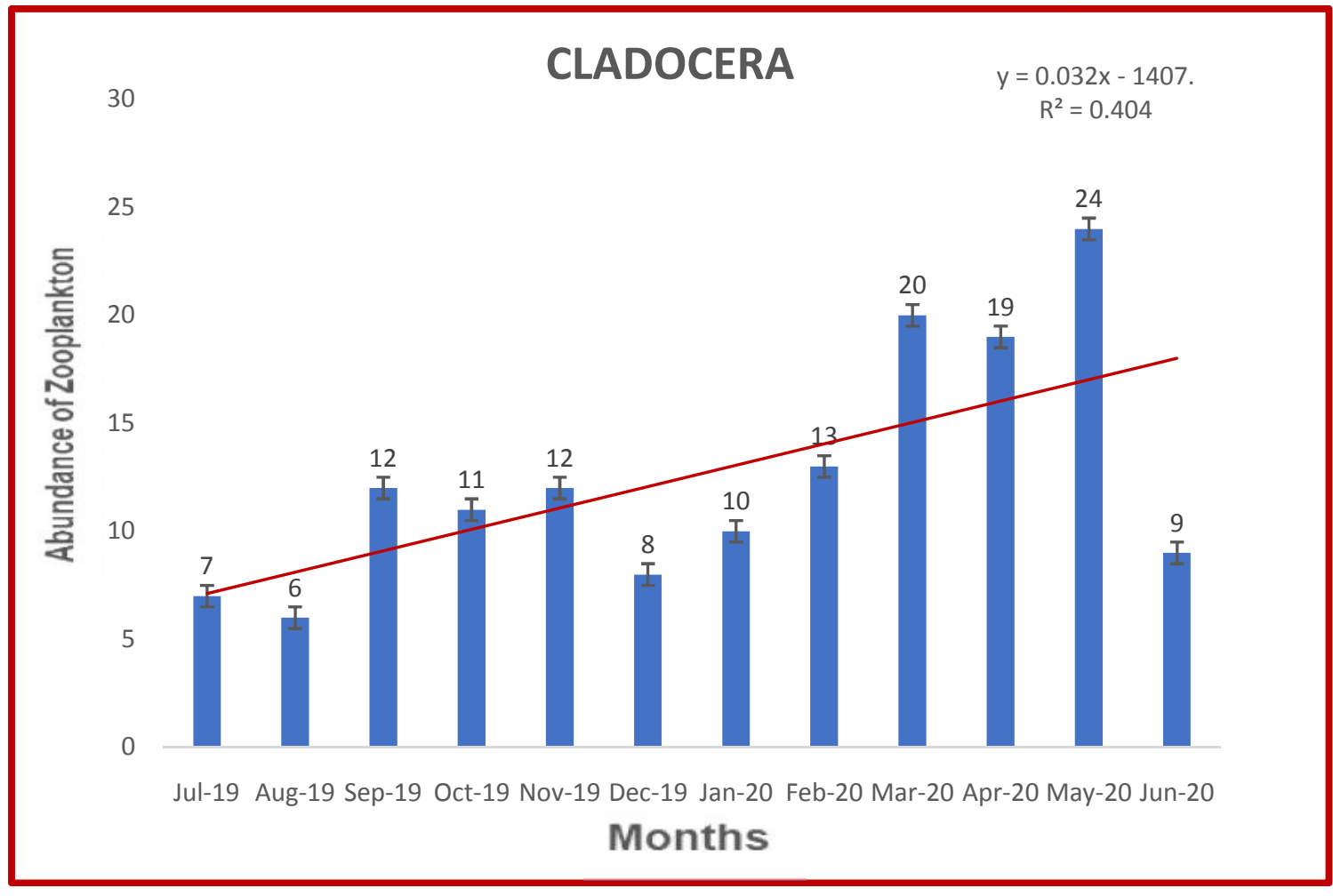

Figure 1: Monthly variation of cladocera throughout the year

\section{Copepoda}

Five species of copepods namely Cyclops $s p$, Tropocyclops sp, Nauplius sp, Diaptomus $s p$ and Heliodiaptomus $s p$ were observed.In the present study, the diversity of copepod during different months of the year was recorded (Table 1) but maximum population occurred between March to May. Among five species of copepods abundance of Cyclops, Nauplius and Heliodiaptomus were observed throughout the year. In winter few species were observed but maximum found in summer. Cyclops were found to maximum from March to April in summer but decreased population observed in winter and rainy season. Tropocyclops sp. was found to be absent in winter from November to February but present in summer and rainy days as well.

Diaptomus $s p$. density was observed as even distribution throughout the year but maximum in March. Heliodiaptomus sp population not observed during rainy season from June to September. The maximum diversity of copepods was observed from February to June and dropped in winter from November to January (Table 1) and few species not found during monsoon. Thus, copepod's positive correlation with temperature indicated their better development during warm period (Figure 2). 


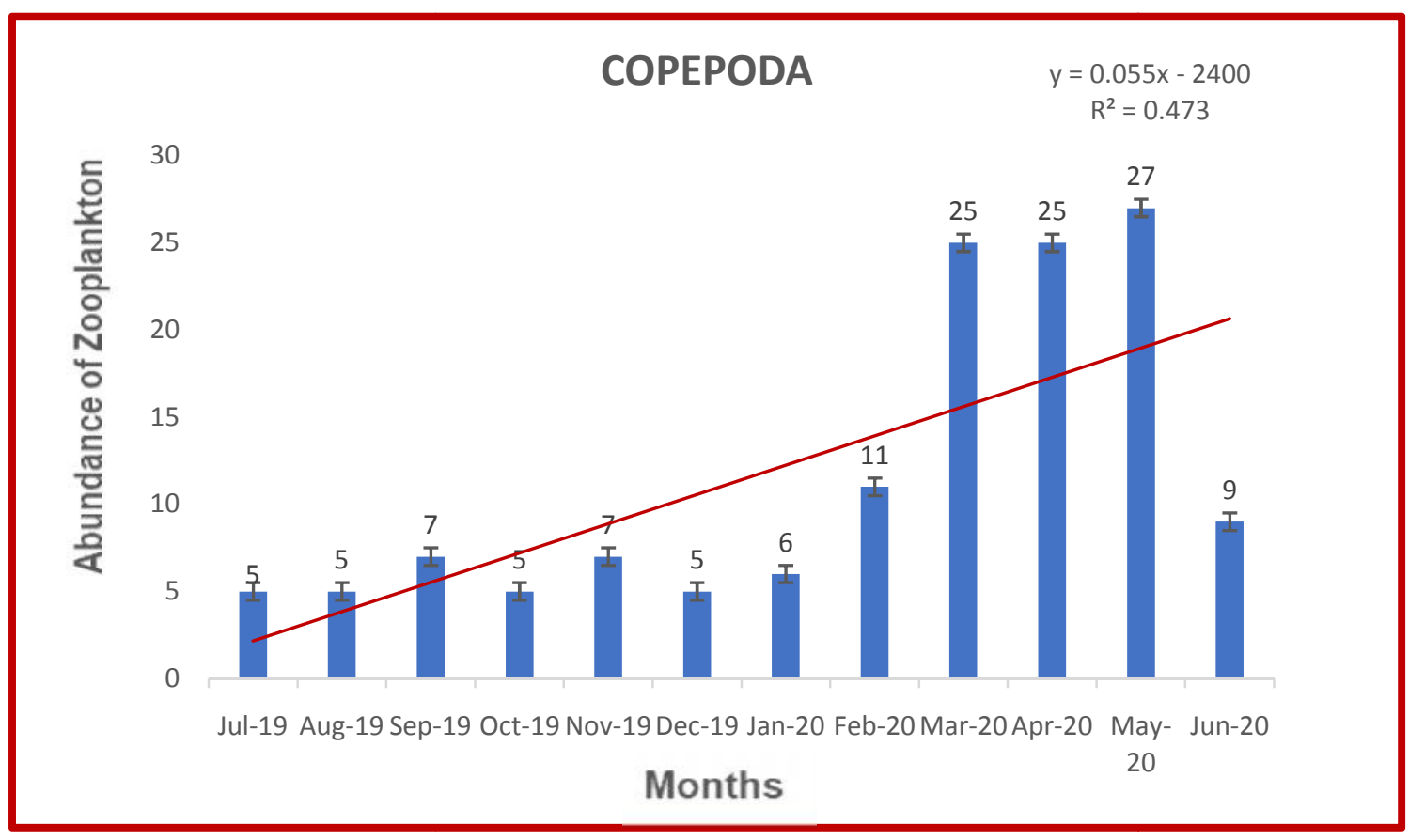

Figure 2: Monthly variation of copepods throughout the year

\section{Rotifera}

In the present study, the rotifers diversity sequence was observed Brachionus $s p>$ Filinia $s p>$ Conochilus sp.Among three species of rotifers, Brachionus $s p$ andFilinia $s p$ were observed throughout the year with high population in summer and low in rainy and winter seasons. It was observed that
Conochilus $s p$ was absent from July to January but abundance of Conochilus $s p$ start to decrease during rainy season and even not observed in end of monsoon and winter. The rotifera group Brachionus $\mathrm{sp}$ is an indicator of organic pollution was present throughout the year. Consequently the rotifers are globally documented as pollution indicator organisms in the aquatic environment (Figure 3).

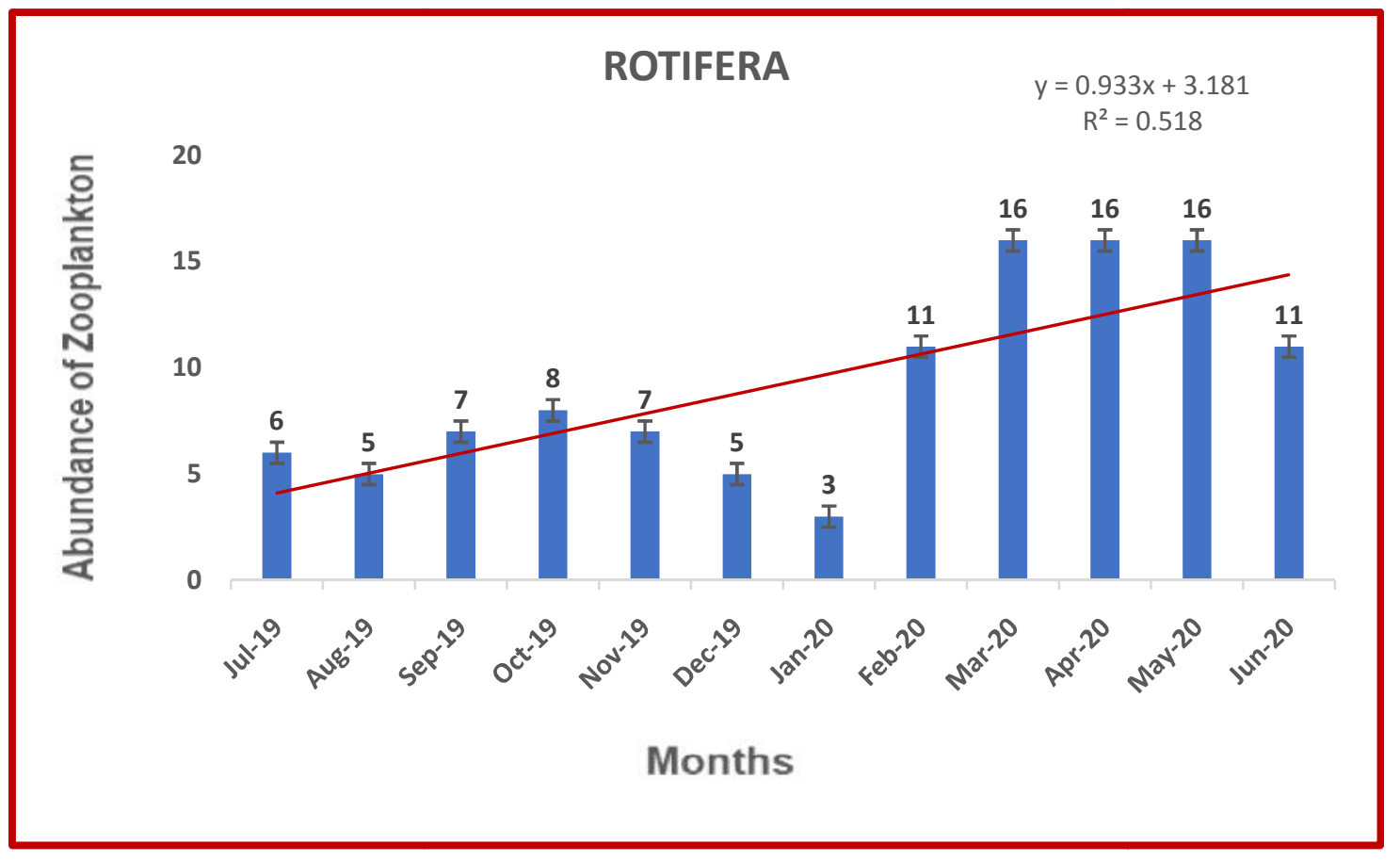

Figure 3: Monthly variation of rotifers throughout the year 


\section{Ostracoda}

Two species of ostracoda viz. cypris $s p$ and Stenocypris sp.were observed during the study period. Population of ostracods was maximum in summer i.e. from march to June and decreased during winter from December to February (Figure 4).

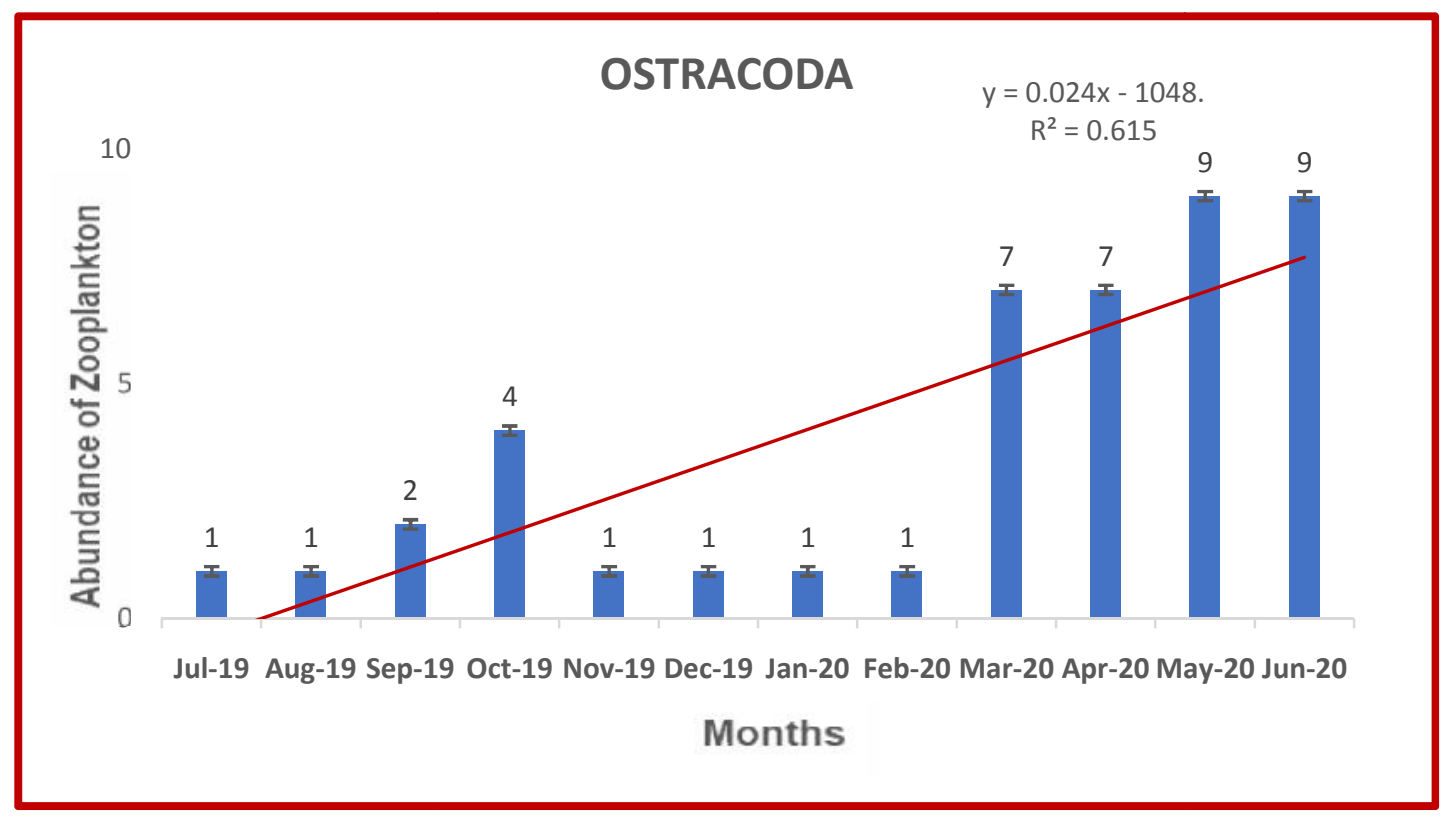

Figure 4: Monthly variation of Ostracoda throughout the year

\section{Physico chemical parameters}

Water temperature ranged between $19{ }^{\circ} \mathrm{C}$ to $26.1^{\circ} \mathrm{C}$ and $\mathrm{pH}$ ranged from 7.3 to 8.3 of Pampoo Pond during the study period respectively. The range of dissolved oxygen (DO) was found between 7.1 to $7.5 \mathrm{ppm}$. Alkalinity (Alk) ranged between 70.0 to 79.0 ppm and total hardness ranged between 95 to 110 ppm of Pampoo Pond respectively. Phosphate ranged between 0.1 to $0.3 \mathrm{ppm}$ and Nitrate ranged between 2.1 to $3.1 \mathrm{ppm}$ respectively throughout the study period of one year (Table 2 and Figure 5).

Table 2: Observation of all Physico - chemical parameter during study period

\begin{tabular}{|l|c|c|c|c|c|c|c|}
\hline Months & \multicolumn{9}{|c|}{ Parameters } \\
\hline & Tem & pH & $\begin{array}{c}\text { Total } \\
\text { Hardness }\end{array}$ & Alkalinity & $\begin{array}{c}\text { Dissolved } \\
\text { Oxygen }\end{array}$ & $\begin{array}{c}\text { Phosphate } \\
\text { (PO4) }\end{array}$ & $\begin{array}{c}\text { Nitrate } \\
\text { (NO3) }\end{array}$ \\
\hline Jul-19 & 26.1 & 7.6 & 90 & 76 & 7.4 & 0.1 & 2.4 \\
\hline Aug-19 & 25.8 & 7.4 & 97 & 75 & 7.4 & 0.2 & 2.5 \\
\hline Sep-19 & 26.2 & 7.6 & 95 & 77 & 7.3 & 0.1 & 2.5 \\
\hline Oct-19 & 24 & 7.5 & 98 & 73 & 7.5 & 0.3 & 2.4 \\
\hline Nov-19 & 21.2 & 7.3 & 102 & 72 & 7.5 & 0.2 & 2.6 \\
\hline Dec-19 & 19.2 & 8.1 & 99 & 70 & 7.4 & 0.2 & 2.4 \\
\hline Jan-20 & 19 & 8.3 & 108 & 71 & 7.2 & 0.3 & 2.3 \\
\hline Feb-20 & 19.3 & 7.8 & 110 & 79 & 7.1 & 0.2 & 2.1 \\
\hline Mar-20 & 19.7 & 7.4 & 107 & 73 & 7.4 & 0.1 & 2.5 \\
\hline Apr-20 & 23.1 & 7.4 & 98 & 72 & 7.3 & 0.2 & 2.5 \\
\hline May-20 & 25.7 & 7.3 & 99 & 71 & 7.2 & 0.2 & 3 \\
\hline Jun-20 & 25.9 & 7.5 & 104 & 70 & 7.4 & 0.2 & 3.1 \\
\hline $\begin{array}{l}\text { Average of } \\
\text { 12 months }\end{array}$ & 22.9 & 7.6 & 100.58 & 73.25 & 7.34 & 0.19 & 2.52 \\
\hline
\end{tabular}




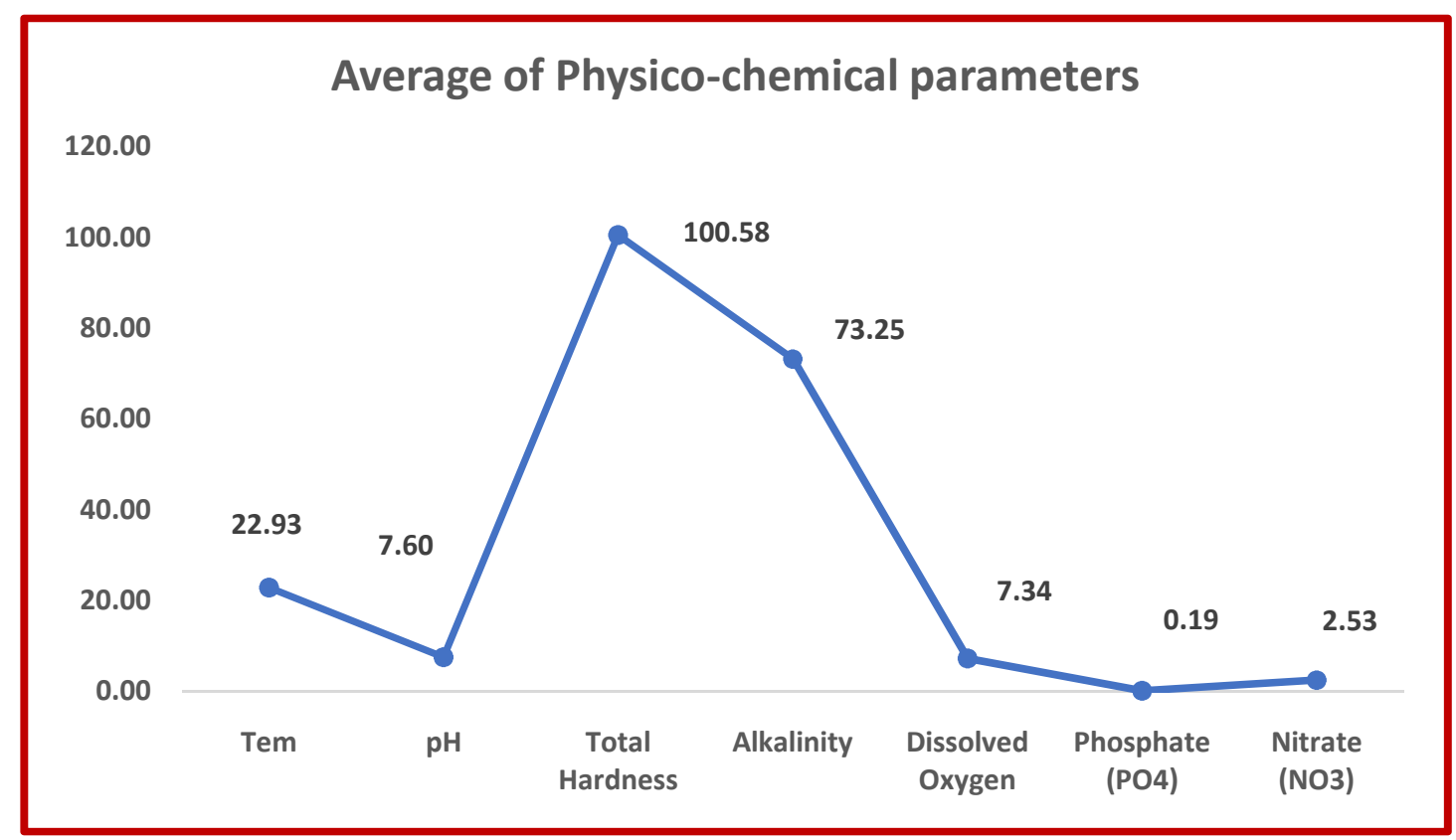

Figure 5. Graph showing the average physico chemical parameters of Pampoo Pond

\section{Discussion}

Effect of seasonal variation on zooplankton diversity is studied by few researchers but till date no proper information available from Deoghar district of Jharkhand. Present work indicated the diversity pattern of zooplanktons of Pampoo Pond in one year time span. Occurrence of very few zooplanktons were observed in July, August, January and February. Again population increased in September, October but less than May and June. This study clearly revealed that maximum density observed in summer and minimum in rainy seasons. Marneffe et al., (1996) reported that the population of rotifers was high in summer and deprived in winter possibly due to high population of bacterial species and organic matter of dead and decaying vegetation. Rotifers respond very quickly to environmental changes than other planktonic species. The rotifers were dominant in municipal and industrial discharges while copepods and cladocerans were less abundant. Choubey, (1997) observed the high density of copepod during October because the water temperature and availability of food to organisms which actually affected the copepod population during summer. Pullie and Khan, (2003) reported that cladocerans mostly observed during winter season may be due to favourable temperature and availability of food, nanoplankton, suspended detritus. The physicochemical factors like DO, water temperature and turbidity also play crucial role in diversity and density of cladocerans. Bohra and Kumar, (2004) however documented that cladocerans were abundant from March to June and were either absent or present in very negligible numbers during the rest of months. Winkler, (2002) reportedthe rise in atmospheric temperature caused enhancement in the evaporation rate and the positive correlation of copepods with temperature indicated their better development in warm periods after winter. Pandey et al., (2009) reported that decline in the number of cladocerans during rainy months may be due to race between cladocerans and other groups of zooplankton however the cladoceran richness was also reported higher in summer and minimum in winter. Zooplankton peak was observed during summers and least abundance of these microscopic animals was recorded in monsoons. Sudden reduction in the zooplankton population during the rainy season as noticed in the present findings could be due to sudden fall of temperature and dilution in concentration of minerals and salts in wetland water. Dominance of cladocera among zooplankton peak was found during summer night be due to optimal thermal and nutritional conditions and lower concentration of oxygen. Effect of rains may explain low records of cladocerans from July to 
September. Copepods developed better in warm periods as noticed in the present study and lesser abundance of copepods during monsoons as recorded in the present study.

Physico-Chemical parameters effect the population density of zooplankton. That's why this objective was carried out to know the status of Pampoo Pond by using standard methods from July 2019 to June 2010. Physico chemical parameters were assessed on monthly basis for one year period. All the physico-chemical parameters found within the range prescribed by ISO 10500-1991. In 1967 Hutchinson reported that the rotifera group Brachionus sp is an indicator of organic pollution and it is very common in temperate and tropical waters that showed the alkaline nature of water. Again Wilhm and Dorris, (1968) reported that the rise in diversity of zooplankton were signal of the healthier environmental state while less diversity suggested fewer species dominance most likely due to sewage environmental pressure. Das et al (1996) carried out experiment to know the environmental conditions of Tasek lake. He established relationship between zooplankton community structure and physicochemical parameters (phytoplankton densities, $\mathrm{pH}$, alkalinity, nitrates and phosphates) by calculating Shannon diversity index $\left(\mathrm{H}^{\prime}\right)$, Evenness index $(\mathrm{J})$ and Species Richness index (S) and analyzing their interrelationship. It was found that $\mathrm{H}^{\prime}$ and $\mathrm{J}$ are closely related while no relationship with Zooplankton densities were positively correlated with species Richness, phytoplankton densities, $\mathrm{pH}$ and alkalinity and negatively correlated with Evenness (J). Community of Copepods and Cladocerans were found where copepods were abundant. This abundance indicated the stable environmental conditions of Tasek lake. According to Siddiqi and Chandrasekhar (1996) Trichotria tetratis could be used as the pollution indicator as they were found in the lake which was rich in phosphorus and other heavy metal ion. This species also found in past in sewage polluted tank. Not only phosphorous and metal ion but also high total alkanity, total hardness and high conductivity of the water of that lake played as limiting factor for the growth of zooplankton. By qualitative and quantitative analysis of the zooplankton community, bioindicator species were selected for analyze water quality (Siddiqi and Chandrasekhar, 1996). Sarkar and Chowdhury, (1999) reported that the fluctuation of abiotic factors i.e., concentration of dissolve oxygen, temperature, total alkalinity, total nitrogen, phosphate and $\mathrm{pH}$ can influence the growth of zooplankton.

Jain et al., (1997) reported that temperature influences the physical, chemical and biological conditions of the ponds and $\mathrm{pH}$ indicates the acid-base balance of the water. DO is a measure of amount of gaseous oxygen dissolved in an aqueous solution that plays a vital role in the biology of cultured organisms. McLeay et al., (2001) reported that the high value of alkalinity indicates the presence of weak and strong base such as carbonates, bicarbonates and hydroxides. Total hardness of water depends on the dissolved solids and $\mathrm{pH}$. Phosphate although present in very small quantity in water is important for the production of phytoplanktons, which forms food for fishes. Nitrate concentration of ground water and surface water may be attributed to the biochemical and anthropogenic sources like fertilizers in agricultural practice. Nutrient availability influences the predominance of rotifers and copepods (Kumar et al., 2006).

Kamble and Meshram, (2005) documented rotifers globally as pollution indicator organisms in the aquatic environment. Sousaet al (2008) reported that structure of zooplankton assemblages was significantly influenced by different water quality of four man- made lakes in a tropical semi- arid region. This response of zooplankton assemblages to water quality of these lakes, caused by eutrophication and siltation, was investigated by means of canonical correspondence analysis. Brachionus calyciflorus, Thermocyclops sp. and Argyrodiaptomus sp. were good indicators of eutrophic condition and $B$. dolabrotus, Keratella tropica and Hexarthra mira were good indicators of high turbidity due to suspended sediments.

Ferdous and Muktadir, (2009) explained that in most of the cases zooplankton population size 
was correlated with biotic and abiotic parameters $(\mathrm{pH}$, alkalinity, temperature, dissolve oxygen, transparency, phosphate, chlorine). Species of Rotifers, Cladocerans, Copepods and Ostracods were found in all cases. Species variation of these order deceased in polluted water. Some species were not found in some highly polluted area though these species have high tolerance level. All the results of the studies indicating that potentiality of zooplankton as bio indicator is very high. Other countries can develop these concepts to monitor water quality. Manjare (2015) has also done qualitative and quantitative study on zooplankton to explain seasonal variation and water analysis in Kolhapur Maharashtra.

Due to their short life span, the zooplankton community often exhibits quick and dramatic changes in response to the changes in the physico-chemical properties of the aquatic environment. They do not only form an integral part of the lentic community but also contribute significantly, the biological productivity of the fresh water ecosystem (Kumar et al., 2006).Khan and Tahesin, (2016) deals with study of diversity zooplankton of Triveni lake. The work was carried out for the period of one year that is December 2012 to November 2013. The zooplankton of Triveni lake water is represented by five different groups like Protozoa, Rotifera, Cladocera, Copepoda, Ostracods with 19 different species were identified and recorded in Triveni lake. Rotifera dominant among zooplankton and this indicates the polluted nature of the lake water. Kaur et al., (2018) reported that the temperature was most important factor that affects the copepods density and diversity. Their production increased with increase in temperature. This may be due to the fact that the higher temperature increased the biochemical \& biological activities and increased the production of microorganisms.

Anbalagan and Sivakami (2019) had done work on the distribution and diversity of zooplankton in aquatic ecosystem depends mainly on the physico-chemical properties of water. Zooplankton have been considered as ecological importance organisms. The present system contained a total of 22 species of zooplankton belonging to Protozoa, Rotifera,
Cladocera, Copepoda, Ostracoda and Anostraca. A percentage comparison among the various zooplankton species reveals that the rotifers were the dominant group forming $50 \%$ of the zooplankton followed by cladocerans and copepods representing $13.7 \%$ each. This was followed by Ostracoda and Protozoa representing 9\% each followed by Anostraca forming $4.6 \%$ of the total zooplankton. Thus, each group of zooplankters preferred to reach their peak in different months of the year. Zooplanktons have immense value as food and play an important role in disposal of sewage and natural purifiers of water. Thus zooplankton diversity is one of the most important ecological parameter in water quality assessment. Zooplankton population is effected by the seasonal variations and they show different pattern of diversity in different month of year. Results of the present work documented the earlier work done by various researchers.

\section{Conclusion}

Present study revealed 15 genera of Zooplankton from the fresh water pond belonging to the four groups namely Cladocera, Rotifera, Copepoda and Ostracoda. Among all four group maximum abundance of Cladocerans (34\%) were observed (Table 2). Five species of cladocerans, five species of copepods, three species of rotifers and two species of ostracods were observed. Among cladocerans Daphnia sp. Ceriodaphnia sp, Alonella sp, Diaphanosoma $s p$, and Moina $s p$. and in copepods Cyclops sp, Tropocyclops $s p$, Nauplius sp, Diaptomus $s p$ and Heliodiaptomus $s p$. were identified respectively. Among rotifers Brachionus $s p$, Filinia $s p$ and Conochilus $s p$ observed. Only two $s p$ namely cypris $s p$ and Stenocypris sp.were observed in ostracoda. The present investigation clearly showed that the maximum density and diversity observed in summer and minimum in rainy seasons. Present study revealed that the Physico chemical parameters of this pond was found to be almost suitable for domestic use and aquatic life form. All parameters are found in the permissible limit. This study is an attempt to list out Indian freshwater zooplankton in a 
single platform from Jharkhand state. For improved study an attentive procedure with better ideas and instrumentation is required.

\section{Acknowledgments}

The author are thankful to management of Deoghar College, Deoghar, Department of Zoology, Sido Kanhu Murmu University, India.

\section{References}

A.P.H.A, (1998). Standrad methods for the examination of water and waste water. American Public Health Associations, New York.

Anbalagan, R., \& Sivakami, R. (2019). Freshwater Phytoplankton Diversity of Mayanur Dam, Tamil Nadu, India. International Journal of Research and Analytical Reviews, 4(1), 94-102.

Battish, S. K. (1992). Freshwater zooplankton of India. Oxford and IBH Publishing Co., New Delhi. 233.

Bohra, S., Kumar, K. (2004). Plankton diversity in the wetlands of Jharkhand. In: Kumar A (ed)) Biodiversity Environ. APH Publishing Corporation, New Delhi (India), 91122.

Choubey, U. (1997) Population dynamics of copepods in relation to water quality of Jannapura Tank. J Aqua Biol. 21(2):67-71.

Contreras, J. J., Sarma, S. S. S., Merino-lbarra, M., \& Nandini, S. (2009). Seasonal changes in the rotifer (Rotifera) diversity from a tropical high altitude reservoir (Valle de Bravo, Mexico). Journal of Environmental Biology, 30(2), 191-195.

Edmondson W.T. (1959). Freshwater Biology 2nd Ed. John Wiley and Sons Inc., New York: 1-1248.

Ferdous Z. and Muktadir (2009) A Review: Potentiality of Zooplankton as Bioindicator American Journal of Applied Sciences 6 (10): 18151819

Ganesan, L., \& Khan, R. A. (2008). Studies on the ecology of zooplankton in a floodplain wetland of West Bengal, India. In Proceedings of Taal2007: The 12th World lake Conference (pp. 67-73).

Hutchinson, G. E. (1967). A treatise on limnology, introduction to lake biology and the limnoplankton (Vol. 2). Wiley.

Jain, C. K., BHATIA, K. S., \& Vijay, T. (1997). Ground water quality in a coastal region of Andhra Pradesh. Indian Journal of Environmental Health, 39(3), 182-192.

Kamble, B. B., \& Meshram, C. B. (2005). A preliminary study on Zooplankton diversity at

\section{Conflicts of Interest}

The authors declare no conflict of interest.

Khatijapur tank, near Achlapur, District Amravati, Maharastra. J Aqua Biol, 20(2), 45-47.

Kar, D. (2007). Fundamentals of Limnology and Aquaculture Biotechnology: A Treatise on the Limnology and Fisheries of the Water Bodies in Southern Assam, Mizoram and Tripura. Daya Books.

Kar, D., \& Barbhuiya, M. H. (2004). Abundance and diversity of zooplankton in Chatla Haor, a floodplain wetland in Cachar district of Assam. Environment and ecology, 22(1), 247-248.

Kar, S., \& Kar, D. (2016). Zooplankton diversity of a freshwater wetland of Assam. International Journal of Advanced Biotechnology and Research, 7(2), 614-620.

Kaur, A., Hundal, S. S., \& Aulakh, R. K. (2018). Seasonal study of zooplankton diversity in the polluted water stretch of Buddha Nullah, Ludhiana. Journal of Entomology and Zoology Studies, 6(5), 2241-2245.

Khan, M. A. (1987). Observations on Zooplankton Composition, Abundance and Periodicity in two Flood-plain Lakes of the Kashmir Himalayan Valley. Acta hydrochimica et hydrobiologica, 15(2), 167-174.

Khan, R. A. (2002). The ecological and faunal diversity of two ox-bowlakes of southeastern West Bengal. Record Zoological Survey of India. Occasional paper, (194), 1104.

Khan R. A. (2003) Faunal diversity of zooplankton in freshwater wetlands of south-eastern West Bengal. Record Zoological Survey of India. Occasional Paper. (204),1107

Khan, R. M., \& Pathan, T. D. (2016). Study of Zooplankton diversity in Triveni lake at Amravatidistrict of Maharashtra. Journal of Global Biosciences, 5(7), 4315-4319.

Kumar, D. S., Sukumar, N. C., Jana, C., \& Philipose, M. T. (2006). Study on physico-chemical characteristics of Thunga River. Phykos, 32, 27-39.

Manjare, S. A. (2015). Qualitative and quantitative study of zooplankton from fresh water tanks of 
kolhapur district,(maharashtra). Research Journal of Life sciences, Bioinformatics, Pharmaceuticals and Chemical Sciences, 1(1), 54-58.

Marneffe, Y., Descy, J. P., \& Thomé, J. P. (1996). The zooplankton of the lower river Meuse, Belgium: seasonal changes and impact of industrial and municipal discharges. Hydrobiologia, 319(1), 1-13.

McLay, C. D. A., Dragten, R., Sparling, G., \& Selvarajah, N. (2001). Predicting groundwater nitrate concentrations in a region of mixed agricultural land use: a comparison of three approaches. Environmental pollution, 115(2), 191204.

Miah, M. F., Roy, S., Jinnat, E., \& Khan, Z. K. (2013). Assessment of Daphnia, Moina and Cylops in freshwater ecosystems and the evaluation of mixed culture in laboratory. American International Journal of Research in Formal, Applied \& Natural Sciences, 4(1), 1-7.

Pandey, B. N., Ambasta, O. P., Thakur, A. K., Sanjay, K., \& Ritu, K. (2009). Zooplankton diversity in relation to certain physico-chemical parameters of swamp of Kishangani District, Bihar. Environment Conservation Journal, 10(1\&2), 9-14.

Pulle, J. S., \& Khan, A. M. (2003). Studies on zooplanktonic community of Isapur Dam water, India. Pollution Research, 22(3), 451-455.

Rai, D. N., \& Dutta-Munshi, J. M. (1982). Ecological characteristics of chaurs of North Bihar. Wetlandsecology and management, 2, 89-95.

Rajagopal, T., Thangamani, A., Sevarkodiyone, S. P., Sekar, M., \& Archunan, G. (2010). Zooplankton diversity and physico-chemical conditions in three perennial ponds of Virudhunagar district, Tamilnadu. Journal of Environmental Biology, 31(3), 265-272.

Singh, S., Kumari, V., Usmani, E., Dutta, R., Kumari, R., Kumari, J., ... \& Arif, M. (2021). Study on Zooplankton Diversity in A Fresh Water Pond (Raja Bandh) of Jamtara, Jharkhand, India. International Journal of Advancement in Life Sciences Research, 4(2), 5-13.

Sarkar, S. K., \& Chowdhury, B. (1999). Role of some environmental factors on the fluctuations of plankton in a lentic pond at Calcutta. Limnological Research in India. Delhi: Daya Publishing House, 108-130.

Sharma, B. K., \& Sharma, S. (1998). Freshwater Rotifers (Rotifera: Eurotatoria). Fauna of West Bengal. State Fauna Series, 3(11), 341-461.

Sharma, B. K., \& Sharma, S. (1998). Freshwater Rotifers (Rotifera: Eurotatoria). Fauna of West Bengal. State Fauna Series, 3(11), 341-461.
Sharma, S., \& Sharma, B. K. (2008). Zooplankton diversity in floodplain lakes of Assam. Zoological Survey of India. Occasional paper no 290: 1-307.

Siddiqui, S. Z., \& Chandrasekhar, S. V. A. (1996). New distribution record of Trichotria tetractis (Rotatoria/Trichotridae) and Daphnia lumholtzi (Brachiopoda/Cladocera/Daphnidae) from Kolleru lake, Andhra Pradesh with notes on indicator value. Journal of Bombay Natural History Society, 93(2), 309-310.

Das, S. K. (2002). Primary production and zooplankton biodiversity in brackish water shrimp culture pond. Journal of Ecobiology, 14(4), 267-271.

Singh, S., Kumari, V., Usmani, E., Dutta, R., Kumari, R., Kumari, J., ... \& Arif, M. (2021). Study on Zooplankton Diversity in A Fresh Water Pond (Raja Bandh) of Jamtara, Jharkhand, India. International Journal of Advancement in Life Sciences Research, 4(2), 5-13.

Sinha, P. K., \& Singh, R. (2016). Seasonal zooplankton diversity in relation to physico-chemical parameters of perennial pond of Chaibasa, West Singhbhum, Jharkhand. Int. J. of Bioassays, 5(9), 4906-4908.

Sousa, W., Attayde, J. L., Rocha, E. D. S., \& Eskinazi-Sant'Anna, E. M. (2008). The response of zooplankton assemblages to variations in the water quality of four man-made lakes in semi-arid northeastern Brazil. Journal of Plankton Research, 30(6), 699-708.

Steinberg, D. K., \& Condon, R. H. (2009). Zooplankton of the York River. Journal of Coastal Research, (10057), 66-79.

Wilhm, J. L., \& Dorris, T. C. (1968). Biological parameters for water quality criteria. Bioscience, 477-481.

Winkler, H. M. (2002). Effects of eutrophication on fish stocks in Baltic lagoons. In Baltic Coastal Ecosystems (pp. 65-74). Springer, Berlin, Heidelberg. 